\title{
KONTEKSTY \\ EFEKTYWNOŚCI KSZTAŁCENIA NA ODLEGŁOŚĆ NA PODSTAWIE CENTRÓW KSZTAŁCENIA PRAKTYCZNEGO I CENTRÓW KSZTAŁCENIA USTAWICZNEGO W POLSCE. WYNIKI TERENOWYCH BADAŃ JAKOŚCIOWYCH
}

\begin{abstract}
Chomczyński Piotr, Kurczewska Agnieszka, Konteksty efektywności kształcenia na odległość na podstawie Centrów Kształcenia Praktycznego i Centrów Kształcenia Ustawicznego w Polsce. Wyniki terenowych badan jakościowych [Contexts of Distance Learning Effectiveness due to the Activity of Centers for Professional Education and Centers for Continuing Education in Poland. Results of a Qualitative Field Study]. Studia Edukacyjne nr 36, 2015, Poznań 2015, pp. 33-54. Adam Mickiewicz University Press. ISBN 978-83-232-2958-2. ISSN 1233-6688. DOI: 10.14746/se.2015.36.3

The aim of this paper is to discuss the sense of distance learning in order to distinguish conditions and effectiveness contexts of distance learning. To achieve this research aim the explorative approach with qualitative methods has been applied. The field study was conducted in institutions of distance learning in Poland. Basing on the Extended Case Method of Burawoy, the paper investigates experiences of the personnel responsible for implementing distance learning in these institutions. As a result, the diagnosis of key characteristics of distance learning method has been made,which enables better understanding of distance learning and outlining new directions of its development in future.
\end{abstract}

Key words: qualitative field study, Burawoy method, Centers for Professional Education, Centers for Continuing Education, distance learning, blended learning

\section{Wstęp}

Rozwój idei społeczeństwa opartego na wiedzy oraz upowszechnienie technologii multimedialnych spowodowały liczne zmiany w charakterze i dostępności edukacji na wszystkich jej szczeblach. Powstaje nowa kultura uczenia się, w której naczelnymi wartościami są: dostępność, ciągłość, ela- 
styczność i aktualność przekazywanych treści. Podstawą budowania społeczeństwa opartego na wiedzy jest realizacja koncepcji uczenia się przez całe życie (kształcenia ustawicznego), funkcjonującej również w polskiej nomenklaturze pod anglojęzycznym terminem lifelong learning. Według definicji unijnej lifelong learning oznacza:

kształcenie ogólne, szkolenie i kształcenie zawodowe, a także kształcenie pozaformalne i nieformalne podejmowane przez całe życie, dzięki czemu ulega polepszeniu poziom wiedzy, umiejętności i kompetencji wymaganych z perspektywy osobistej, obywatelskiej, społecznej lub zawodowej¹.

Realizacja koncepcji uczenia się przez całe życie wymogła spopularyzowanie kolejnych nowych obszarów w edukacji, w tym przede wszystkim idei kształcenia na odległość (distance learning) KnO, które Główny Urząd Statystyczny definiuje jako:

rodzaj kształcenia, w którym przekazywanie treści oraz sprawdzenie jego przebiegu i efektów odbywa się z zastosowaniem dostępnych technik komunikacyjnych, w szczególności poczty, poczty głosowej, poczty elektronicznej, telewizji lub Internetu, bez stałego i bezpośredniego kontaktu nauczającego i uczącego się².

Kształcenie na odległość, zarówno w swej „czystej” formie (e-learning), jak również jako element uczenia mieszanego (blended learning), zredefiniowało możliwości współczesnej edukacji. Początkowo traktowane raczej eksperymentalnie, obecnie staje się stałym elementem kształcenia na wszystkich poziomach i w większości profili instytucji edukacyjnych. Zaistniałe zmiany wydają się wychodzić poza sfery techniczną i infrastrukturalną, które są relatywnie proste $\mathrm{w}$ adaptacji, a główną barierą wdrażania jest brak środków na zakup sprzętu umożliwiającego realizację kształcenia na odległość. Większym i bardziej czasochłonnym wyzwaniem staje się zmiana sposobu myślenia osób zaangażowanych $\mathrm{w}$ proces edukacji. Pojawienie się nowych sposobów i form nauczania umożliwiających kształcenie na odległość spowodowało rewolucję $\mathrm{w}$ postrzeganiu procesu uczenia, zostawiając więcej samodzielności i odpowiedzialności za przebieg tego procesu po stronie uczącego się. Nauczyciele z kolei muszą pozyskać nowe kompetencje, zmodyfikować metody nauczania oraz weryfikacji wiedzy i umiejętności. Zaznacza się także silna tendencja w kierunku wizualizacji procesu kształcenia (visual lerning) poprzez coraz szersze wykorzystanie treści przekazywanych

${ }^{1}$ Decyzja nr 1720/2006/WE Parlamentu Europejskiego i Rady z 15 listopada 2006 r. ustanawiająca program działań w zakresie uczenia się przez całe życie - DzU L 327 z 24.11.2006.

2 Źródło: http://old.stat.gov.pl/gus/definicje_PLK_HTML.htm?id=POJ-5371.htm [dostęp: 30.07.2014]. 
za pomocą obrazu ${ }^{3}$. Zmienia się forma komunikacji i interakcji między uczniami a nauczycielami, której jednak powinna towarzyszyć po obu stronach wysoka świadomość procesów uczenia się.

Mimo ogromnych zalet w postaci na przykład: swobody uczenia, jego elastyczności czasowej czy możliwości wielokrotnego odtwarzania treści programowych przez uczących się, pojawiają się również wątpliwości co do uniwersalności, a przede wszystkim efektywności kształcenia na odległość. Przyjmując stanowisko krytyczne, należy zastanowić się, przy jakich uwarunkowaniach kształcenie na odległość przynosi najwięcej korzyści dla edukacji i jakie czynniki powodują, że jakość edukacji zdalnej staje się wysoka. Celem artykułu jest dyskusja nad zasadnością zdalnej edukacji, w rezultacie której wyodrębnione zostaną warunki i konteksty efektywności kształcenia na odległość. Realizacja tak postawionego celu badawczego wymaga podejścia eksploracyjnego. Zdecydowano się na jakościowe badania terenowe realizowane $\mathrm{w}$ instytucjach wdrażających koncepcję zdalnej edukacji. Opierając się na metodzie rozszerzonych przypadków Burawoya, zbadano doświadczenia osób zaangażowanych w proces kształcenia na odległość i określono jego cechy charakterystyczne. Badania, w zamyśle, przyczyniają się do lepszego zrozumienia specyfiki kształcenia na odległość, jak również mogą stać się przyczynkiem do refleksji na temat kierunków rozwoju tej formy kształcenia.

\section{Problematyka kształcenia na odległość}

Specyfika kształcenia na odległość. Choć przytoczona we wstępie artykułu definicja kształcenia na odległość skupia się na sposobie przekazywania treści, specyfika tej formy kształcenia oraz jej znaczenie jest daleko szersze. W wyniku wdrożenia $\mathrm{KnO}$ zmienia się przede wszystkim organizacja i przebieg procesów uczenia, a nie tylko sposób komunikacji między stronami. Z upowszechnieniem kształcenia na odległość wiążą się zmiany o charakterze społecznym, naukowym i dydaktycznym, psychologicznym oraz ekonomicznym.

Rozwój koncepcji kształcenia na odległość jest naturalną konsekwencją zachodzących zmian cywilizacyjnych i skłania do reinterpretacji potrzeb współczesnego społeczeństwa. Postęp naukowy i technologiczny, globalizacja, wysokie tempo życia i rosnący poziom życia wpłynęły na oczekiwania

${ }^{3}$ Por. M. Szpilska, Raport krajowy na temat stanu wizualizacji uczenia się w Polsce, Radom 2006. 
wobec edukacji. Wyzwaniem stało się zapewnienie kształcenia, które dopasowane jest do zmiany trybu życia uczących i nadąża za odkryciami naukowymi, czyli umożliwia aktualizację przekazywanych treści, które mogą być absorbowane $\mathrm{w}$ dowolnym czasie, miejscu i za pomocą różnorodnych metod. Coraz większy nacisk zaczęto również kłaść na masowość edukacji (dostępność dla jak najszerszej części społeczeństwa), przy jednoczesnej jej indywidualizacji (dopasowanie do potrzeb jednostek, wykazujących różne predyspozycje i zgłaszających różne potrzeby).

Rozważając kształcenie na odległość z punktu widzenia rozwoju edukacji i dydaktyki, warto podkreślić, że jego cele są zbieżne z celami klasycznej, czyli stacjonarnej, edukacji ${ }^{4}$. Priorytetowym zadaniem edukacji jest dostarczenie wiedzy, wzmocnienie kompetencji i kreowanie postaw umożliwiających jednostce funkcjonowanie w społeczeństwie i przyczynianie się do jego rozwoju. Różni je sposób komunikacji między uczącymi a uczącymi się, charakter ich interakcji, pakiet zastosowanych metod i form nauczania. Kształcenie na odległość cechuje asynchroniczność, co powoduje, że wymaga ono wzmożonej aktywności i zaangażowania w proces uczenia. Wpisuje się zatem we współczesne paradygmaty edukacji, a zwłaszcza w konstruktywistyczny model uczenia się. Zgodnie z konstruktywistycznym modelem procesy edukacyjne koncentrują się wokół uczenia się (learning), a nie nauczania (teaching $)^{5}$. Uczący się

tworzą i zarządzają własnym procesem uczenia się, który jest otwarty na różne treści, style, cele, doświadczenia etc. oraz pozwala im skorzystać z każdej sposobności, by uzyskać odpowiedź na pojawiające się pytania ${ }^{6}$,

czyli związane jest raczej z procesami głębokiego rozumienia, niż tylko pozyskiwania wiedzy. Podejście konstruktywistyczne związane jest również z rozwojem świadomości, zajmowaniem krytycznego stanowiska, podważaniem faktów i poddawaniem rzeczywistości refleksjom. $W$ tradycyjnym modelu edukacja jest skoncentrowana na procesie nauczania, a wiedza przekazywana uczniowi w sposób raczej pasywny, co w praktyce często prowadzi do statycznych wykładów i małej liczby przedsięwzięć edukacyjnych opartych na interakcji, a $\mathrm{w}$ większym stopniu polega na nauce pamięciowej. W kształceniu na odległość wykorzystuje się częściej metody pozwalające większej grupie uczących na bieżąco angażować się w tema-

${ }^{4}$ J. Bednarek, E. Lubina, Kształcenie na odległość. Podstawy dydaktyki, Warszawa 2008.

${ }^{5}$ N. Krueger, The microfoundations of entrepreneurial learning and education. The handbook of university wide entrepreneurship, Cheltenham, UK 2009.

${ }^{6} \mathrm{H}$. Löbler, Learning entrepreneurship from a constructivist perspective, Technology Analysis \& Strategic Management, 2006, 18(1), s. 19-38. 
tykę zajęć. Uczestnictwo w forach, tworzenie blogów i vlogów, czy komentowanie treści programowych wyzwala w uczących się postawę refleksyjną i krytyczną.

Zmiany w dydaktyce $\mathrm{KnO}$ wymagają zmiany w sposobie postrzegania procesów uczenia się przez uczniów i nauczycieli. Z punktu widzenia psychologii procesu uczenia się istotne staje się zrozumienie, że kształcenie na odległość opiera się na samokształceniu, potrzebna jest więc dużo większa samodzielność, odpowiedzialność i dojrzałość uczących się ka i Małgorzata Taraszkiewicz dodatkowo podkreślają niezbędny poziom motywacji i odpowiednie nastawienie, które determinuje wytrwałość i efektywność w przyswajaniu wiedzy ${ }^{8}$. Proces uczenia się ma charakter bardziej indywidualny, wymagający od nich zazwyczaj większej systematyczności i rygoru uczenia się oraz aktywności. Oparty jest na samoświadomości uczących się odnośnie celu i potrzeby uczenia się oraz dużego wpływu na jego przebieg i rezultaty. Obok koncentracji nauczycieli na jakości i aktualności przekazywanej wiedzy oraz przydatności rozwijanych umiejętności, kształcenie na odległość wymaga od nich intensywnego motywowania uczących się do nauki i większej kreatywności w tworzeniu programów nauczania. Często również motywuje do aktualizowania udostępnianych treści programowych i doskonalenia znajomości technologii informatycznych.

$\mathrm{Z}$ punktu widzenia ekonomicznego wprowadzenie kształcenia na odległość wymaga nakładu środków na stworzenie infrastruktury (zwłaszcza platformy internetowej umożliwiającej kontakt między stronami), jak również na przygotowanie multimedialnych materiałów dydaktycznych. Jak zauważa Dziewulak, w przypadku KnO konieczne staje się zastosowanie takich dedykowanych systemów informatycznych, jak: system do zarządzania szkoleniami LMS (Learning Management Systems), system do zarządzania treścią szkoleniową LCMS (Learning Content Management System), system do zarządzania komunikacją synchroniczną LCS (Life Communication System) ${ }^{9}$. Ułatwiają one proces kształcenia na odległość, jednak wymagają również nakładów finansowych.

Wśród największych korzyści wynikających z wdrożenia kształcenia na odległość wymienia sięi1:

7 Por. E. Szczęsna, Dyskurs kształcenia digitalnego. Ontologia dyskursu kształcenia digitalnego i jego funkcje, Studia Edukacyjne, 2013, 26, s. 280.

${ }^{8}$ Cz. Plewka, M. Taraszkiewicz, Uczymy się uczyć, Szczecin 2010, s. 55-57.

9 D. Dziewulak, Kształcenie na odległość w wybranych państwach europejskich. Analizy, Biuro Analiz Sejmowych, 2012, 18(85), 24 października, s. 2.

${ }^{10} \mathrm{~J}$. Bednarek, E. Lubina, Ksztatcenie na odległość; tamże. 
- elastyczność uczenia się, czyli możliwość realizacji nauki niezależnie od miejsca i czasu oraz dostosowania metod do zróżnicowanej grupy odbiorców;

- angażowanie wszystkich konstrukcji osobowości i inteligencji w proces uczenia (emocji, woli, konstrukcji kognitywnych), powodujących lepsze przyswajanie treści programowych;

- większą aktywność wszystkich osób zaangażowanych w $\mathrm{KnO}$;

- dostępność kształcenia dla szerszego grona osób, w tym osób wykluczonych, oszczędność (zarówno dla instytucji zaangażowanej $\mathrm{w} \mathrm{KnO}$, zwłaszcza w perspektywie długoterminowej, jak i dla uczących się) $)^{11}$.

Z kolei, do najistotniejszych wad kształcenia na odległość można zaliczyć12:

- większą anonimowość procesu uczenia się i mniejszą kontrolę nad nim przez uczących;

- osłabienie relacji międzyludzkich, wynikające z ograniczonego kontaktu bezpośredniego między uczestnikami kształcenia;

- ograniczoność przekazywanych treści programowych (zwłaszcza w przypadku dziedzin eksperymentalnych);

- ograniczenie funkcji wychowawczej nauczycieli;

- problemy z uznawalnością dyplomów czy certyfikatów wydawanych w wyniku ukończenia edukacji o charakterze zdalnym;

- problemy prawne (np. związane z prawem autorskim czy ochroną danych osobowych).

Zatem, w literaturze można wskazać wiele zalet $\mathrm{KnO}$, ale także podejść krytycznych do problemu jego uniwersalności czy efektywności. Celem tego artykułu nie jest jednak ani promowanie, ani podważanie zasadności kształcenia na odległość (jest to forma kształcenia, która stanowi stały i potrzebny element systemu edukacji), lecz wskazanie obszarów, w których jest ono najbardziej efektywne oraz określenie warunków, jakie należy spełnić w celu zmaksymalizowania jego przydatności i skuteczności.

Problem oceny efektywności KnO. Specyfika kształcenia na odległość powoduje, że typowe formy weryfikacji wiedzy nie spełniają swojego zadania. Zakładając, że poprzez efektywność rozumiany jest postęp $\mathrm{w}$ nauce, opanowanie pewnej partii materiału $\mathrm{w}$ określonym czasie przez odsetek uczestników potwierdzony uzyskaną przez nich wiedzą, umiejętnościami i postawami, $\mathrm{KnO}$ wymaga wypracowania nowych reguł i standardów oce-

${ }^{11}$ J. Bednarek, E. Lubina, Ksztatcenie na odległość, s. 99-101.

12 Tamże; D. Dziewulak, Kształcenie na odległość w wybranych państwach europejskich. 
ny uczniów. Jest to jednak tylko jeden wymiar oceny efektywności procesów nauczania. Jednym z najbardziej popularnych modeli kompleksowego badania efektywności szkoleń jest metoda Donalda Kirkpatricka, na którą składają się cztery poziomy oceny ${ }^{13}$ :

1) poziom reakcji - polega na badaniu wrażeń uczestników szkoleń, ich zdania na temat szkolenia i poziomu zadowolenia; techniką pomiaru są przede wszystkim ankiety i rozmowy;

2) poziom nauki - związany jest $z$ oceną stopnia pozyskanej wiedzy i umiejętności; techniką pomiaru są przede wszystkim testy i sprawdziany;

3) poziom zachowania - sprowadza się do określenia wpływu szkolenia na zachowanie i postawy po zakończeniu szkolenia, oceniana jest tutaj zmiana w zachowaniu spowodowana nabytą wiedzą i kompetencjami; technika pomiaru zasadza się przede wszystkim na obserwacji i analizie zachowań;

4) poziom rezultatów - polega na ocenie wpływu szkolenia na uzyskanie wymiernych korzyści przez firmę/instytucje, w której uczestnik szkolenia pracuje; techniką pomiaru są przede wszystkim wywiady i obserwacje.

Metoda ta ma z całą pewnością uzasadnienie w przypadku kształcenia na odległość. Wymaga jednak wypracowania standardów i mierników, za pomocą których można byłoby ocenić efekty kształcenia.

\section{Metodologia badań}

Metoda. Prezentowane w artykule wyniki badań jakościowych opierają się na metodzie rozszerzonych przypadków Burawoya, która zakłada dokonanie etnograficznej analizy organizacji z wykorzystaniem wszelkich dostępnych źródeł informacji14 celem diagnozy zjawisk, których ilościowa eksploracja jest utrudniona. Są to $\mathrm{z}$ reguły zjawiska subtelne, których ujawnienie wymaga od badacza uzyskania zaufania od ludzi, wśród których przebywa $^{15}$. Metoda ta zakłada rozciągniętą w czasie, bezpośrednią obserwację procesów zachodzących w danej instytucji poprzez fakt fizycznej obecności badacza i prowadzenia rozmów ${ }^{16}$, niekiedy nieformalnych i niejako „przy

13 D.L. Kirkpatrick, Ocena efektywności szkoleń, Warszawa 2001.

14 Por. M. Kostera, Antropologia organizacji: Metodologia badań terenowych, Warszawa 2003.

15 Por. P. Chomczyński, Wybrane problemy etyczne w badaniach. Obserwacja uczestniczaca ukryta, Przegląd Socjologii Jakościowej, 2006, II, 1.

16 Por. M. Burawoy, The Extended Case Method. Four Countries, Four Decades, Four Great Transformations, and One Theoretical Tradition, Los Angeles 2009, s. 46-47. 
okazji", z jej członkami17. Obserwacja badanych w środowisku organizacyjnym umożliwia bezpośredni dostęp do danych empirycznych, dzięki czemu zminimalizowaniu ulega wpływ czynników stojących pomiędzy badaczem a przedmiotem badań1 ${ }^{18}$. Dzięki zebranym danym istnieje możliwość pewnej generalizacji zbadanych zjawisk, odnoszących się do określonego typu instytucji, na szerszą populację ${ }^{19}$. Atutem przemawiającym na rzecz metod terenowych jest fakt, że opierają się one na gromadzeniu i wykorzystaniu różnych źródeł wywołanych i niewywołanych, które z kilku perspektyw dają możliwość formułowania sądów na temat badanej rzeczywistości. Jak zauważają Thomas Eberle i Christoph Maeder ${ }^{20}$ :

wykonywanie etnografii oznacza użycie wielu metod zbierania danych, takich jak: obserwacja, wywiady, pozyskanie dokumentów, fotografii, materiałów audiowizualnych i innych materiałów reprezentujących artefakty. (...) badacz wykonuje pracę terenową i zbiera dane poprzez fizyczną obecność.

W przypadku omawianych tutaj badań, w każdej placówce przeprowadzono pięciodniowe obserwacje, które $\mathrm{w}$ rezultacie łącznie liczyły 400 godzin, a także 50 wywiadów strukturalizowanych, również we wszystkich placówkach. Materiał empiryczny został także poszerzony o nieformalne rozmowy, przeprowadzone $\mathrm{z}$ osobami, które poza sytuacją wywiadu spontanicznie odnosiły się do wybranych kwestii związanych z kształceniem na odległość.

Klucz doboru placówek do badania. Sposób doboru placówek do badania w poczynionym przez nas założeniu miał odzwierciedlać różnice występujące pomiędzy nimi w obszarach, które mają charakter kluczowy dla ich działalności. Zaliczono do nich następujące czynniki:

- doświadczenia placówki w zakresie KnO;

- doświadczenia w zakresie wykorzystania przeszłych i obecnych funduszy UE;

- dostępne zasoby ludzkie (specjaliści z dziedziny e-learningu);

${ }^{17}$ K. Konecki, Studia z metodologii badań jakościowych: teoria ugruntowana, Warszawa 2000, s. 147.

18 Por. Ch. Frankfort-Nachmias, D. Nachmias, Metody badawcze w naukach społecznych, przekł. E. Hornowska, Poznań 2001, s. 223; M. Patton, Obserwacja - metoda badań terenowych, [w:] Ewaluacja w edukacji, red. L. Korporowicz, przekł. M. Kowalski, Warszawa 1997, s. 167.

19 Por. M. Burawoy, The Extended Case Method, s. 23.

20 Przekł. własny T. Eberle, Ch. Maeder, Organizational ethnography, [w:] Qualitative Research, $3^{\text {rd }}$ Edition, Ed. D. Silverman, London 2011, s. 54; por. także M. Kostera, Antropologia organizacji, s. 142 . 
- dostępne zasoby edukacyjne w zakresie $\mathrm{KnO}$ (oferta kursów opartych na $\mathrm{KnO}$, ich zróżnicowanie).

Fakt wyraźnego zróżnicowania badanych instytucji edukacyjnych daje możliwość dokonania cząstkowej diagnozy stanu kształcenia na odległość w Polsce w zakresie centrów kształcenia praktycznych CKP, centrów kształcenia ustawicznego CKU oraz centrów kształcenia ustawicznego i praktycznego CKUiP. Odmienne doświadczenia placówek w prowadzeniu kursów opartych na $\mathrm{KnO}$, jak również doświadczenia w pozyskiwaniu środków unijnych stwarzają możliwość porównania postaw kierownictwa i kadry wobec idei $\mathrm{KnO}$ oraz wzajemnej współpracy obydwu grup i dalszych planów rozwijania tej metody kształcenia. O zasadności przyjęcia kryteriów zróżnicowania w zakresie doświadczeń placówek przesądza fakt występowania odmiennych postaw kierownictwa i personelu, a także przyjmowanych strategii rozwojowych $\mathrm{w}$ ramach polityki edukacyjnej badanych instytucji.

Próba badawcza. Ma ona charakter ogólnopolski, wskutek czego odzwierciedla uwarunkowania geograficzne pozwalające na ostrożną generalizację wniosków badawczych. W skład populacji badanych instytucji weszły następujące placówki:

1) Regionalny Ośrodek Kształcenia na Odległość w Krośnie (Zespół Szkół Kształcenia Ustawicznego);

2) Centrum Kształcenia Praktycznego w Nowym Sączu;

3) Centrum Kształcenia Ustawicznego w Koninie;

4) Centrum Kształcenia Ustawicznego w Krakowie;

5) Centrum Kształcenia Ustawicznego w Sopocie;

6) Centrum Kształcenia Ustawicznego w Toruniu;

7) Łódzkie Centrum Kształcenia Praktycznego i Doskonalenia Nauczycieli;

8) Centrum Kształcenia Ustawicznego i Praktycznego w Zielonej Górze;

9) Centrum Kształcenia Ustawicznego w Wałbrzychu;

10) Szkoła Komputerowa „Impuls” w Gliwicach.

Zróżnicowanie geograficzne placówek odzwierciedla różne ich doświadczenia w zakresie $\mathrm{KnO}$, wsparcia instytucjonalnego, dostępu do wykształconej kadry pedagogicznej i technicznej, a także determinuje kształt populacji osób decydujących się na wzięcie udziału w programie. W konsekwencji, prezentowane $\mathrm{w}$ artykule wnioski pozwalają na kompleksową prezentację czynników decydujących o efektywności KnO.

Zasada triangulacji. Jak wiadomo, $u$ podstaw idei triangulacji $w$ badaniach społecznych leży chęć spojrzenia na dane zjawisko $\mathrm{z}$ wielu różnych 
perspektyw. Krzysztof Konecki pisze, że dzięki triangulacji badacz ma szansę „ukazać siebie jako zewnętrznego obserwatora zjawisk, nawet wtedy, gdy jest $\mathrm{w}$ jakimś stopniu ich uczestnikiem"21. Triangulacja ma przynieść badaczowi możliwość uwolnienia się od jednego, dominującego sposobu oglądu i interpretacji rzeczywistości na korzyść stosowania kilku perspektyw jednocześnie ${ }^{22}$. W ramach szerokiego terminu "triangulacja” można wyodrębnić różne jej odmiany, zaproponowane w 1978 roku przez Normana K. Denzina ${ }^{23}$, które można odnieść do metodologii przyjętej w badaniach:

- triangulacja danych - użycie danych z różnorodnych źródeł. W przypadku niniejszych badań wykorzystywano informacje udzielane przez:

a) kierownictwo placówek (dyrektorzy i zastępcy dyrektorów placówek lub/i kierownicy odpowiedzialni za $\mathrm{KnO}$ w placówce),

b) nauczycieli zaangażowanych $\mathrm{w} \mathrm{KnO}$,

c) pedagogów i psychologów zatrudnionych w badanych placówkach,

d) informatyków (jeśli w placówce takie osoby wspomagały nauczycieli w tworzeniu, przygotowywaniu i umieszczaniu materiałów dla uczniów/ słuchaczy),

e) uczestników $\mathrm{KnO}$ - w kilku placówkach przeprowadzono z nimi rozmowy (indywidualne, zbiorowe, np. podczas szkolenia wprowadzającego, oraz telefoniczne, odbywane $\mathrm{w}$ trakcie pobytu w placówce, jak również poza nią);

- triangulacja badacza - wprowadzenie do badań wielu obserwatorów lub kontrolerów badań i wniosków. Rolę kontrolerów (na etapie zbierania i analizowania informacji) pełnili członkowie zespołu badawczego, a także osoby odpowiedzialne za $\mathrm{KnO}$ w badanych placówkach, z którymi konsultowane były poszczególne wnioski badawcze;

- triangulacja metodologiczna - użycie wielu metod w celu zbadania pojedynczego problemu. Wypracowane w tym badaniu wnioski opierają się na obserwacji jawnej uczestniczącej, wywiadach ustrukturalizowanych i prowadzonych rozmowach nieformalnych oraz licznej dokumentacji wewnętrznej badanych placówek. Ponadto, badacze uzyskali także dostęp do jednej z platform z poziomu użytkownika, pozwalającej na lekturę newslettera i innych informacji bieżących.

${ }^{21}$ K. Konecki, Studia z metodologii badań jakościowych, s. 85.

${ }^{22}$ L. Keashly, K. Jagatic, US perspectives on workplace bullying, [w:] Bullying and Emotional Abuse in the Workplace. International perspectives in research and practice, Eds S. Einarsen, H. Hoel, D. Zapf, C.L. Cooper, London-New York 2003, s. 44-45.

${ }^{23}$ Cyt. za K. Konecki, Studia z metodologii badań jakościowych, s. 86. 


\section{Charakterystyka placówek}

Placówki typu CKU. Badania objęły siedem² ${ }^{24}$ placówek typu CKU. Różnią się one ze względu na ofertę programową (od kilkunastu do prawie 80 kursów wykorzystujących $\mathrm{KnO}$ w formie szkolnej i pozaszkolnej), jej różnorodność, liczbę słuchaczy/uczniów, a także infrastrukturę w zakresie posiadanego sprzętu komputerowego oraz stopnia jego modernizacji. We wszystkich placówkach funkcjonują licea ogólnokształcące (w jednej z nich profilowane), w większości szkoły zawodowe, technika oraz szkoły policealne zaoczne i stacjonarne. Nauczanie realizuje się w trybie dziennym, wieczorowym i zaocznym, z mniejszym bądź większym wykorzystaniem e-learningu, który zawsze ma charakter blended learningu i nie występuje w "czystej” postaci.

Zróżnicowanie obejmuje także mniej bądź bardziej bogaty wachlarz dostępnych pozaszkolnych form kształcenia w postaci kursów i szkoleń, umożliwiających zdobycie uprawnień zawodowych. Niektóre placówki nie mają w swojej ofercie pozaszkolnych kursów i szkoleń, inne zaś dysponują nawet kilkunastoma, co wskazuje na dużą różnorodność w zakresie oferty KnO skierowanej do odbiorców.

Placówki typu CKP. Badaniami objęto dwie placówki tego typu. Mimo że obydwie instytucje należą do jednego typu, to jednak profil ich działalności, jak też oferta oraz liczba uczniów/słuchaczy różni je od siebie w sposób znaczący. W ramach placówek typu CKP można zaobserwować także znaczącą odmienność zarówno w liczbie kursów wspomaganych $\mathrm{KnO}$ (w jednej placówce 5, zaś w drugiej 25 kursów, w obu przypadkach stanowi to kilka procent ogólnej liczby prowadzonych kursów), jak również w procentowym udziale osób nimi objętych (odpowiednio 40-60\% w przypadku placówki, w której prowadzonych jest 5 kursów i 3\% w drugim przypadku). Zróżnicowanie obejmuje także liczbę nauczycieli, którzy odbyli studia podyplomowe z zakresu KnO. W pierwszej placówce jest to jeden nauczyciel na 30 osób, zaś w drugiej - dziesięciu nauczycieli stanowiących 11\% kadry.

\section{Wyniki badań empirycznych}

Zebrany materiał empiryczny $w$ postaci licznych obserwacji, jak i wywiadów oraz nieformalnych rozmów prowadzonych z kadrą kierowniczą,

${ }^{24} \mathrm{~W}$ celu dochowania zasady anonimowości, do placówek CKU włączono jedyną w badaniu placówkę CKUiP w Zielonej Górze. Włączenie nastąpiło po konsultacji z kierownictwem placówki. 
nauczycielami oraz kursantami pozwala na wprowadzenie taksonomii czynników wpływających na efektywność kształcenia na odległość.

Inicjatywa i umiejętność pozyskania środków unijnych na budowę lub rozbudowę infrastruktury technicznej. Na podstawie analizy rozmów prowadzonych $\mathrm{z}$ kierownictwem i pracownikami wspomnianych wyżej instytucji, które pozyskały środki unijne dla realizacji i rozwoju $\mathrm{KnO}$, można stwierdzić, że $\mathrm{w}$ opinii badanych placówki te są liderami regionalnymi w zakresie kształcenia ustawicznego i praktycznego oraz doświadczeń z zakresu KnO. W niniejszych placówkach można także zauważyć entuzjastyczne nastawienie kierownictwa i nauczycieli wobec idei $\mathrm{KnO}$, a także perspektywy kontynuacji tego typu kształcenia w przyszłości. Odmienne postawy dominują natomiast tam, gdzie nie podejmowano się uczestnictwa $\mathrm{w}$ programach unijnych $\mathrm{z}$ zakresu $\mathrm{KnO}$ lub starania o pozyskanie środków $z$ dotacji europejskich nie przyniosły pożądanego rezultatu.

$\mathrm{W}$ jednej z placówek typu CKU realizowano wcześniej projekty unijne, które kontynuowane są także obecnie (EFS PO KL). Dzięki nim zmodernizowano sprzęt, stworzono materiały do $\mathrm{KnO}$ i poszerzono program zajęć. Z kolei, w innej placówce typu CKU także zrealizowano w przeszłości kilka projektów finansowanych przez Unię Europejską, z których jeden realizowany jest do dzisiaj. Środki pochodzące z programów unijnych zostały także wykorzystane w przypadku jednej placówki typu CKP. Ponadto, w ramach projektu RPO zdobyto środki na doposażenie pracowni mechatronicznej, co w znacznym stopniu zwiększyło atrakcyjność oferty szkoleniowej.

Dotychczasowe doświadczenia związane z KnO. Ważny okazał się także temporalny wymiar doświadczeń związanych z realizacją KnO. Tutaj da się zauważyć pewną prawidłowość, mianowicie w placówkach, w których $\mathrm{KnO}$ istnieje od dłuższego czasu panuje także bardziej pozytywne nastawienie do idei e-learningu, $\mathrm{w}$ której upatruje się zdobycie przewagi konkurencyjnej istotnej w kontekście niżu demograficznego. Jeden z dyrektorów placówki stwierdził, że możliwość kształcenia w ramach $\mathrm{KnO}$ znacznie uatrakcyjnia oferte, zwłaszcza w oczach młodych ludzi, którzy chcieliby pobierać naukę bez wychodzenia $z$ domu. W tych placówkach sięga się także od lat po środki unijne. Te z kolei warunkują zarówno poszerzenie szkolnej i pozaszkolnej oferty edukacyjnej, modernizację sprzętu komputerowego oraz parku maszynowego, co zwrotnie wpływa na jeszcze większe zadowolenie i wiarę w $\mathrm{KnO}$ wśród personelu. 
Zaangażowanie kadry kierowniczej oraz personelu. We wszystkich badanych placówkach inicjatorami i najczęściej osobami nadzorującymi KnO (mniej bądź bardziej formalnie) są dyrektorzy lub/i kierownicy projektu $\mathrm{KnO}$, którzy wcześniej uczestniczyli w studiach podyplomowych z zakresu e-learningu. Jedna osoba kierująca placówką typu CKU stwierdziła, że KnO stato się moja pasja, która starałem się zarazić innych. Widze w tym przyszłość ksztatcenia.

W placówkach, w których istnieje zewnętrzne finansowanie $\mathrm{KnO}$ (w ramach projektu unijnego) daje się zauważyć wyraźne zaangażowanie nauczycieli w proces poszerzania oferty kursów wykorzystujących $\mathrm{KnO}$, jak również wzbogacanie i aktualizowanie prowadzonych przez siebie kursów. Jedna z nauczycielek z placówki typu CKU stwierdziła, że realizacja $\mathrm{KnO}$ w ramach środków unijnych daje mi możliwość uzyskania dodatkowych źródet zarobku, co na początku drogi zawodowej jest dla mnie szczególnie istotne.

Należy podkreślić, że różnice $\mathrm{w}$ doświadczeniu $\mathrm{w}$ zakresie $\mathrm{KnO}$ silnie warunkują odmienne podejścia do tego typu kształcenia. W placówkach z większym stażem panuje przekonanie, zarówno wśród kierownictwa jak i nauczycieli, o korzyściach wynikających z e-learningu i potrzebie jego upowszechniania. Opinia taka budowana była przez lata, kiedy $\mathrm{KnO}$ realizowano najczęściej „siłami” młodych nauczycieli, którzy obecnie mają już doświadczenie w tym zakresie i wdrażają młodszych kolegów. W placówkach o niewielkim doświadczeniu $\mathrm{w}$ dziedzinie $\mathrm{KnO}$ e-learning postrzega się raczej w kategoriach pomocniczych wobec kształcenia tradycyjnego lub nawet czasami za coś niepotrzebnego. W placówkach, które nie korzystają z finansowania zewnętrznego kursów wspomaganych $\mathrm{KnO}$, dostrzegalna jest także różnica zdań pomiędzy kierownictwem a pracownikami, gdzie ci ostatni, z uwagi na brak motywacji finansowej oraz konieczność wykonywania dodatkowej (nieopłaconej) pracy $\mathrm{w}$ ramach $\mathrm{KnO}$, nie przejawiają entuzjastycznego nastawienia. Jedna z nauczycielek pracujących w CKU stwierdza, że W moim przypadku KnO to dodatkowa trudność i obciązenie. Przygotowanie lekcji w ramach $\mathrm{KnO}$ trwa zdecydowanie dtużej niż w przypadku lekcji tradycyjnej. Poza tym ja tego po prostu nie czuje, nie jestem entuzjastka tego typu ksztatcenia. Wiem, $\dot{z}$ e wszystko idzie w kierunku informatyzacji, ale ja tego nie czuje.

Współpraca z innymi instytucjami. Wypowiedzi badanych jednoznacznie wskazują, że u podstaw wysokiej efektywności kształcenia na odległość leży udana współpraca $\mathrm{z}$ innymi instytucjami. W przypadku kooperacji są to takie instytucje jak ROKNO 25, inne CKU/CKP organa prowadzące, kurato-

${ }^{25}$ Regionalny Ośrodek Kształcenia na Odległość. 
ria, szkoły wyższe prywatne i państwowe, KOWEZiU 26, urzędy pracy, zakłady karne, inne szkoły średniego lub zawodowego szczebla. W odpowiedzi na pytania o współpracę niejednokrotnie pojawiały się uwagi krytyczne wskazujące na złe relacje $\mathrm{z}$ organami prowadzącymi. Te ostatnie były oskarżane o brak zrozumienia i wsparcia rozwoju $\mathrm{KnO}$ w zakresie budowania infrastruktury, organizacji szkoleń itp. Tam, gdzie współpraca nie jest zadowalająca, również $\mathrm{KnO}$ napotyka na problemy. Jeden nauczyciel z placówki objętej badaniem stwierdził, że urzędnicy z Urzędu Miasta nie rozumieja specyfiki KnO, w zwiazku z tym trudno jest im zrozumieć kłopoty, których doświadczamy. W konsekwencji nasze prośby o pomoc spotykają się z odmową.

W trzech placówkach typu CKU, w których realizowano wcześniej kursy z wykorzystaniem $\mathrm{KnO}$ w ramach programów unijnych, są podejmowane próby nawiązania współpracy z instytucjami zagranicznymi prowadzącymi $\mathrm{KnO}$. Z przeprowadzonych z kierownictwem i personelem rozmów wynika, że większa wola nawiązywania współpracy zagranicznej jest udziałem nauczycieli z tych placówek, które korzystały wcześniej ze środków unijnych przy realizacji i rozbudowie oferty programowej kursów wspomaganych KnO. Byliśmy z wizyta w Hiszpanii i kilku innych krajach Unii Europejskiej i myśle, że to by było korzystne nawiazanie takiej wspótpracy w zakresie KnO. Można wymienić się doświadczeniami, gdyż tam, ta forma nauczania istnieje już od dawna, a my trochę raczkujemy w tym temacie. Uczestnictwo placówki w programach unijnych nie jest jednak warunkiem sine qua non dla wiary w korzyści wynikające ze współpracy międzynarodowej w zakresie KnO. Także w placówkach, które wcześniej nie pozyskały środków unijnych zdarzają się nauczyciele dostrzegający możliwość takiej współpracy i deklarują chęć jej nawiązania. Są oni jednak w mniejszości.

Z wypowiedzi kierownictwa i nauczycieli wynika jednoznacznie, że ważna także okazała się współpraca $\mathrm{z}$ innymi podmiotami w zakresie KnO. Tam, gdzie współpraca z innymi instytucjami ma charakter długoletni i jest oparta na relacjach $\mathrm{z}$ wieloma podmiotami, ogólne nastawienie do idei $\mathrm{KnO}$ jest bardziej przychylne. $\mathrm{W}$ tych natomiast placówkach, w których brak doświadczeń współpracy z innymi podmiotami w ramach $\mathrm{KnO}$, lub współpraca ta nie spełniała pokładanych w niej oczekiwań, postawy kierownictwa i nauczycieli są zdecydowanie bardziej negatywne. Połowa badanych instytucji nie deklaruje współpracy z innymi instytucjami w ramach KnO. Pojawiły się opinie, że ta współpraca była nieefektywna i nie przynosiła spodziewanych korzyści lub inicjatywa współpracy nie została podjęta przez inną instytucję. Jeden z kierowników $\mathrm{KnO}$ wspomina, że próbowaliśmy na-

${ }^{26}$ Krajowy Ośrodek Wspierania Edukacji Zawodowej i Ustawicznej. 
wiązać kontakt w zakresie $\mathrm{KnO}$ z jedna szkoła wyższa o profilu biznesowym, ale druga strona nie była tym zainteresowana, więc inicjatywa utknęła w martwym punkcie. Niekiedy współpraca zakończyła się wraz ze zrealizowaniem określonego projektu.

W jednej z badanych placówek typu CKU panuje silne przekonanie, że ważniejsze od współpracy z innymi instytucjami jest pozyskanie środków finansowych na bieżące potrzeby (modernizacja sprzętu, możliwość dodatkowego wynagrodzenia pracowników), co stworzy możliwość nawiązania dalszej współpracy. Jak stwierdza dyrektor placówki, dla nas najważniejszy jest dostęp do funduszy unijnych, które pozwola nam zmodernizować infrastrukture $i$ zdobyć doświadczenie. Wtedy dopiero możemy myśleć o wspótpracy z innymi, gdyż staniemy się bardziej konkurencyjni.

Standaryzacja kształcenia na odległość. W jednej z placówek typu CKU planuje się powołanie ROKNO i zdobycie pozycji krajowego lub regionalnego centrum $\mathrm{KnO}$, którego celem byłoby doskonalenie nauczycieli i prowadzenie doradztwa metodycznego. Ponadto, istnieją pomysły opracowania krajowego modelu $\mathrm{KnO}$, który nakreślałby standardy $\mathrm{KnO}$, które w przekonaniu badanych są potrzebne, a już obecne w krajach zachodnich. Jeden $\mathrm{z}$ nauczycieli argumentował to opinią, że istnieje konieczność wypracowania pewnych norm, zasad, regut, które standaryzowatyby programy KnO tak żeby nie było takiej dowolności i uznaniowości, jaka jest w chwili obecnej. W zależności od placówki, materiaty, którymi dysponuja nauczyciele w ramach $\mathrm{KnO}$ bardzo różniq się od siebie i to nie jest dobre. Powinny być pewne standardy, które podniosa jakość $\mathrm{KnO}$.

W placówce tej planuje się także uruchomienie warsztatów informatycznych i metodycznych dla nauczycieli zaangażowanych w $\mathrm{KnO}$, żeby wspomóc ich w pracy w ramach $\mathrm{KnO}$. Jak stwierdza dyrektor, dostrzegam wyraźna potrzebę stworzenia warsztatów, na których nauczyciele w sposób praktyczny, a nie teoretyczny, jak to jest na większości kursów, nabyliby wiedzy i umiejętności $w$ zakresie tworzenia atrakcyjnych materiatów stanowiacych podstawe do $\mathrm{KnO}$, lecz także posiedliby umiejętność prowadzenia grupy w ramach KnO. Taka forma nauczania wymaga nieco innego przygotowania, niż kształcenie droga tradycyjna.

W innej placówce typu CKU planuje się zebranie dotychczas wypracowanych materiałów w ramach zakończonego w 2008 projektu: "Centra Kształcenia na Odległość na Wsiach" i udostępnienie ich na zewnątrz. Tego typu działania także są zorientowane na standaryzację $\mathrm{KnO}$ w Polsce i w założeniu służą podniesieniu jakości tej formy nauczania. Osoba odpowiedzialna $\mathrm{w}$ tej placówce za $\mathrm{KnO}$ podkreśliła, że zwarty dokument stanowiący 
podsumowanie i zbiór wniosków z tego projektu, udostępniony innym placówkom przystuży się większemu wykorzystaniu dobrych praktyk i zmniejszy ryzyko popetniania tych samych błędów, które nam się przydarzyły.

Implementacja systemu weryfikacji jakości kształcenia. W zdecydowanej większości badanych placówek system jakości $\mathrm{KnO}$ nie funkcjonuje. Można dostrzec pewną tendencję w tych placówkach, w których realizowane były kursy $\mathrm{z}$ wykorzystaniem $\mathrm{KnO}$, finansowane ze środków unijnych i zaobserwować większe zainteresowanie weryfikacją jakości kształcenia oraz próby stworzenia systemu poprawy jakości kształcenia. Odkąd realizujemy KnO korzystając ze środków unijnych coraz bardziej przymierzamy sie do badania satysfakcji kursantów z jakości ksztatcenia, gdyż Unia będzie tego od nas wymagać. Zastanawiamy się nad opracowaniem takiej ankiety, którą kursanci wypetnialiby elektronicznie (kierownik $\mathrm{KnO}$ w CKU).

Kontrola jakości KnO jest najczęściej realizowana w sposób nieformalny, polegający na logowaniu się kierownictwa placówki na platformę i sprawdzania z poziomu użytkownika funkcjonowania platformy. Najczęściej sprawdza się liczbę logowań nauczycieli i kursantów, sprawdza się posty i ich treści, oceny. Od czasu do czasu wchodze na platformę, loguję się i z poziomu administratora sprawdzam różne statystyki, co daje mi ogólny obraz jak pracuja nauczyciele na platformie. Ponadto, ocenie poddaje się niekiedy wskaźniki zewnętrzne, takie jak na przykład poziom zdawalności egzaminów zewnętrznych. W placówce typu CKU, w której istnieje wdrożony system jakości, KnO zawiera plan ewaluacji, który zakłada badania zadowolenia kursantów i nauczycieli, testy przyrostu umiejętności na skutek odbycia kursu itp. Taki system jest jednak rzadkością wśród badanych placówek.

Niektórzy dyrektorzy wskazują, że brakuje możliwości silniejszego oddziaływania na nauczycieli, jako że nie mają oni właściwie obowiązku brania udziału w $\mathrm{KnO}$, gdyż ich zdaniem nie ma rozporządzeń do ustawy. Wszystko rozbija się o brak prawodawstwa w tym zakresie. Ja nie moge zmusić nauczycieli, by realizowali $\mathrm{KnO}$, gdyż nie maja takiego prawnego obowiazku. Moge ich prosić i przekonywać wskazując na szanse i zagrożenia.

Monitoring zadowolenia odbiorców kształcenia. Podobnie jak w przypadku weryfikacji oceny kształcenia, w zakresie monitoringu zadowolenia odbiorców kształcenia zdecydowanie przeważa brak systemowych rozwiązań. Najczęściej satysfakcję kursantów „bada się” podczas nieformalnych rozmów w ramach konsultacji, egzaminów stacjonarnych lub rzadziej umieszcza się ankietę na platformie. Mam niejednokrotnie okazje porozmawiać $z$ kursantami, gdy przychodza na konsultacje. Często sami informuja co jest nie tak 
i co chcieliby zmienić (kierownik KnO w CKU). Można było zauważyć pewną prawidłowość $\mathrm{w}$ tym względzie. Mianowicie, placówki, które realizowały programy $\mathrm{KnO}$ finansowane ze środków zewnętrznych przykładały także większą wagę do konieczności wprowadzenia systemu badania satysfakcji uczniów, zaś rzadziej nauczycieli. Częściowo plany te stanowiły konsekwencję wymogów stawianych przez UE, częściowo zaś wynikały z kontaktów z innymi placówkami i wzrostu świadomości w zakresie konieczności podnoszenia jakości kształcenia. Jeden z dyrektorów w CKU stwierdził, że $w$ niedtugim czasie będziemy tworzyli system badania satysfakcji nauczycieli $i$ odbiorców kształcenia. To jest pomocne przy modyfikacjach treści programów i poprawy motywacji w pracy nauczyciela.

Możliwość konsultacji ze specjalistami, a także udziału w kursach doszkalających. Konsultacje najczęściej przybierają formę pomocy koleżeńskiej, zwłaszcza kiedy koledzy/koleżanki skończyli studia podyplomowe $\mathrm{z}$ zakresu KnO. Jak zaznacza jeden z nauczycieli w CKU, pomagamy sobie nawzajem, bo tak jest najszybciej i najefektywniej. Najczęściej taka pomoc koleżeńska wystarczy do rozwiazania bieżących problemów, choć czasami pojawia się problem bardziej złożony, wtedy trzeba szukać gdzieś indziej. W jednej z placówek pracownicy uzyskiwali pomoc w ramach Okręgowej Komisji Egzaminacyjnej, w której część z nich pracowała, a gdzie funkcjonowało KnO. Podobnie deklaruje jeden z zastępców kierownika w CKP: Ze względu na fakt, że część $z$ nas pracuje także w Okręgowej Komisji Egzaminacyjnej, to mamy możliwość konsultowania się w niektórych merytorycznych $i$ metodycznych sprawach zwiazanych z KnO. Czasami korzystamy z takiego rozwiazania.

Niekiedy konsultacje odbywają się podczas konferencji, zebrań kierownictwa CKU/CKP. Niektóre osoby wspominały sporadyczną pomoc ze strony uczelni wyższych, na których kończyli studia podyplomowe z zakresu e-learningu, a także konsultacje z KOWEZiU. Jakiś czas temu, gdy byłam na szkoleniu z zakresu KnO miałam okazje zapytać o kilka kwestii natury metodycznej $w$ ramach mojego przedmiotu, to jest chemii. Udało mi się uzyskać ciekawe wskazówki, a przede wszystkim kontakt do tej osoby. Teraz, gdy mam jakiś problem, który wykracza poza moja wiedze, zdarza mi się pisać i taka pomoc uzyskać (jedna $\mathrm{z}$ nauczycielek w CKU).

Sporadycznie zdarzała się taka sytuacja, w której nauczyciele pomimo chęci wzięcia udziału w kursach doszkalających z zakresu $\mathrm{KnO}$, nie mieli takiej możliwości z powodu niewystarczającej liczby miejsc oferowanych przez instytucje szkolące.

Specjalizacja organizacyjna związana z KnO. Najczęściej, ze względów finansowych, brakuje osobnej komórki, która odpowiadałaby za KnO, zaś 
zadania związane z organizacją procesu kształcenia przydzielane są ad hoc nauczycielom, którzy mają wiedzę z zakresu obsługi platformy lub zatrudnionym $w$ placówce informatykom. Instytucje wszystkich typów podkreślały potrzebę posiadania takiej komórki lub stworzenia instytucji, która obsługiwałaby kilka placówek w zakresie tworzenia materiałów, ich aktualizacji, umieszczania na stronie, serwisu platformy i rozwiązywania problemów technicznych $w$ dziedzinie konfiguracji sprzętu, a także dbania o jakość transferu $\mathrm{w}$ ramach Internetu. Jeden $\mathrm{z}$ dyrektorów w placówce typu CKP wyraził opinię, że to byłby dobry pomyst mieć taka komórkę, która zajmowałaby się jedynie pomoca $w$ tworzeniu, czy też wspomaganiu nauczycieli $w$ tworzeniu atrakcyjnych materiałów do KnO. Niestety, nie mamy jednak funduszy, by stworzyć taka komórkę, a informatyków nie moge tym obarczać. Podobne opinie były popularne także wśród nauczycieli, z których jeden stwierdził, że taka komórka jest niezbędna $z$ tego względu, że zbyt wiele się od nas wymaga. Mamy stworzyć materiały, które sa atrakcyjne wizualnie, najlepiej aktywizujące, natomiast skąd na to wziąć czas? Pomijam już kwestię umiejętności i wiedzy.

Wśród badanych pojawiła się nawet opinia stworzenia instytucji centralnej, która obsługiwałaby kilka placówek realizujących $\mathrm{KnO}$, wspomagając je w tworzeniu materiałów dydaktycznych. Żeby zaoszczędzić pieniądze mogłaby być stworzona jakaś instytucja centralna, która wspomagataby kilka placówek realizujacych $\mathrm{KnO}$. Taki nauczyciel mógłby jej wysyłać swoje materiaty, zaś oni dostosowywaliby je do wymogów $\mathrm{KnO}$, dodając różnego rodzaju grafiki czy nawet animacje.

Poszukiwanie rozwiązań niszowych. W kilku badanych placówkach pojawił się projekt skierowania $\mathrm{KnO}$ do osób niepełnosprawnych zarówno ruchowo, jak również o lekkiej niepełnosprawności umysłowej. $\mathrm{W}$ tej idei upatruje się szansę na poszerzenie zarówno oferty edukacyjnej, jak również objęcie kształceniem większej liczby osób. Kierownik KnO wyraził pogląd, że tego typu inicjatywa pozwoli osobom niepetnosprawnym zaangażować się w poprawe własnych kwalifikacji, zdobycie dodatkowej wiedzy, a przez to integracje ze społeczeństwem. Ponadto, w przypadku osób niepetnosprawnych oferta $\mathrm{KnO}$ daje im możliwość zdobycia zatrudnienia i zmiany swojej sytuacji życiowej. W placówce tej istnieją plany zdobycia pozycji lidera w zakresie wykorzystania $\mathrm{KnO}$ w edukacji osób niepełnosprawnych. Konieczne jednak są środki służące dostosowaniu infrastruktury dla potrzeb tych osób i zapewnienia im kompleksowej opieki (także psychologicznej, jako że osoby takie należy motywować w odmienny sposób niż osoby pełnosprawne, jak również inaczej wygląda diagnoza czynników spowalniających postępy w nauce). Tego rodzaju plany, w przekonaniu badanych, wymagają dodatkowych szkoleń i zatrudnienia większej liczby pracowników. 
Uczestnictwo w szkoleniach metodycznych. W przeważającej mierze nauczyciele eksponują potrzeby szkoleń metodycznych, które pozwolą im na konwersję dotychczasowych materiałów dydaktycznych, wykorzystywanych w "tradycyjnych" lekcjach, na materiały służące do realizacji KnO. Kierownictwo jak i nauczyciele zastrzegali, że muszą to być szkolenia odnoszące się do określonych przedmiotów lub grup przedmiotów, nie zaś szkolenia ogólne. $\mathrm{W}$ opinii jednego z kierowników $\mathrm{KnO}$, w placówce typu CKU zbyt wiele jest szkoleń teoretycznych, na których nauczyciel nie ma możliwości treningu, przez co kończy kurs nie potrafiąc w praktyce wykorzystać zdobytych na nim wiadomości. Podobne opinie wygłaszają nauczyciele, którzy brali udział w różnych szkoleniach z zakresu KnO. Jedna z nauczycielek stwierdziła, że zupetnie nie sa mi przydatne kursy ogólne z zakresu KnO. Ja uczę biologii i dla mnie ważne sa kursy przedmiotowe, gdzie mogę dowiedzieć się jak mam stworzyć ciekawa lekcję biologii, a nie jezzyka polskiego! Szkolenia w opinii badanych powinny być ukierunkowane praktycznie tak, żeby kursant potrafił po ukończeniu kursu stworzyć lekcję. Z rozmów wynika, że warunek ten był spełniony zazwyczaj w przypadku studiów podyplomowych, odbytych przez inicjatorów $\mathrm{KnO}$ (najczęściej kierownictwo) w danej instytucji.

Rzadziej badani sygnalizowali potrzebę odbycia kursów informatycznych z zakresu obsługi platformy skierowanej do nauczycieli, którzy jeszcze nie zetknęli się z KnO lub prowadzą $\mathrm{KnO}$, lecz nie mają wystarczającej wiedzy umożliwiającej im sprawne posługiwanie się platformą i wykorzystywanie $\mathrm{w}$ pełni jej funkcji. Potrzeby takie zgłaszane były raczej przez starszych nauczycieli. Jedna z nauczycielek stwierdziła, że ja nie mam za bardzo doświadczenia w pracy z komputerem, a tym bardziej w zakresie korzystania $z$ Internetu. Mnie przydałby się kurs ogólny z zakresu obstugi komputera, wtedy mogłabym wykorzystywać go do $\mathrm{KnO}$.

W praktyce okazuje się, że często wymienione kursy są realizowane „siłami wewnętrznymi", w postaci szkoleń wewnętrznych realizowanych przez nauczycieli, którzy uczestniczyli $\mathrm{w}$ takich szkoleniach $\mathrm{w}$ formie kursów lub studiów podyplomowych. Jak stwierdza jeden z nauczycieli, który wcześniej odbył kurs zewnętrzny, a obecnie sam szkoli kolegów z pracy: od czasu do czasu, gdy jest taka potrzeba, organizujemy takie szkolenie wewnętrzne, majace postać luźnych spotkań zwoływanych ad hoc.

\section{Podsumowanie}

Kształcenie na odległość stanowi równorzędny rodzaj edukacji z jej klasycznymi formami. Nie jest już eksperymentalnym dodatkiem do tradycyj- 
nego nauczania, lecz stałym elementem współczesnego systemu edukacji. Posiada wiele zalet, a jego słabsze strony w dużym stopniu można potraktować jako wyzwania, których pokonanie wymaga większych nakładów czasu, pracy i środków finansowych. Wydaje się jednak, że kontynuacja procesu upowszechniania kształcenia na odległość musi wiązać się z większą świadomością specyfiki tej formy kształcenia. Osoby odpowiedzialne za KnO nie do końca zdają sobie sprawę z możliwości, jakie ono niesie ze sobą i jego ogromnej dynamiki. Potrzebne są szkolenia metodyczne pozwalające zrozumieć wartość zdalnej edukacji, a nie wyłącznie treningi skupiające się na opanowaniu obsługi platform internetowych, czy uczące nowych form dialogu z uczniem (takich jak np. blogi, vlogi, fora internetowe). Należy jednak zdać sobie sprawę, że dla grupy nauczycieli nie posiadających znajomości obsługi komputera i Internetu, kształcenie na odległość nie jest możliwe do realizacji. Wśród uczących jest wyraźny podział na zwolenników i sceptyków tej formy kształcenia. Z uwagi na intensywność kontaktu z uczniami i mnogość kanałów komunikacji, $\mathrm{KnO}$ powinno być realizowane przez nauczycieli zmotywowanych i wykazujących duży entuzjazm, bowiem tylko tacy są $\mathrm{w}$ stanie zachęcić uczniów do systematycznej pracy i tworzyć kreatywne przedsięwzięcia edukacyjne.

Przeprowadzone badania pokazują, że osoby zaangażowane w kształcenie na odległość skupiają się na instytucjonalnych i technicznych aspektach jego funkcjonowania. Mniej uwagi poświęcone jest zmianom o charakterze dydaktycznym czy psychologicznym. Można odnieść wrażenie, że potrzeba zdalnego kształcenia $\mathrm{w}$ wielu przypadkach została narzucona $\mathrm{z}$ góry poprzez instytucje edukacyjne, czy dostępne środki unijne na ich realizację, a nie stanowi rezultatu oddolnej inicjatywy nauczycieli czy uczniów. Skuteczne wdrażanie kształcenia na odległość może zatem przebiegać wolniej i przy mniejszym zaangażowaniu.

Analizując przeprowadzone rozmowy $\mathrm{z}$ osobami zajmującymi się kształceniem na odległość, można odnotować pewne zagubienie i deklarację braku możliwości konsultacji swoich pomysłów. Wspieranie jakości $\mathrm{KnO}$ powinno być priorytetem działań ośrodków edukacyjnych zajmujących się jego wdrażaniem. We wzmocnieniu systemu jakości i wypracowaniu standardów $\mathrm{KnO}$ istotną rolę mogą odegrać tworzące się regionalne i krajowe instytucje kształcenia na odległość.

Istotnym aspektem funkcjonowania kształcenia na odległość, z którym borykają się jego organizatorzy, jest również efektywność prowadzonych zajęć. Aby móc uznać $\mathrm{KnO}$ za efektywne, powinien być spełniony przede wszystkim warunek mierzalności, czyli powinny zostać wypracowane standardy i mierniki, za pomocą których można byłoby ocenić efekty kształcenia. 
Spełnienie tego warunku wiąże się z większym sformalizowaniem procesu kształcenia. Ma to jednak uzasadnienie, zwłaszcza jeśli byłyby one rezultatem wspólnego wypracowania zasad przez społeczności zajmujące się KnO.

W świetle przeprowadzonych badań należy zastanowić się nad przyszłością kształcenia na odległość w Polsce po skończeniu dofinansowania ze środków unijnych na jego rozbudowę.

\section{Zakończenie}

Celem artykułu było podjęcie dyskusji nad zasadnością zdalnej edukacji. W jej wyniku dokonano diagnozy i oceny kształcenia na odległość w wybranych instytucjach zajmujących się $\mathrm{KnO}$ w Polsce. Jak wynika z badań, kształcenie na odległość przynosi najwięcej korzyści dla edukacji, kiedy spełniony jest warunek zaangażowania i świadomego uczestnictwa wszystkich uczestników szkoleń, zarówno nauczycieli jak i uczniów. Od strony instytucjonalnej konieczne jest zbudowanie systemu kształcenia na odległość z instytucją koordynującą i ewaluującą działania jednostek edukacyjnych zaangażowanych w $\mathrm{KnO}$, rejestrem szkoleń $\mathrm{KnO}$ i ich certyfikacją. Do innych czynników powodujących, że jakość edukacji zdalnej staje się wysoka zaliczyć można:

- różnorodność form przekazywanych treści programowych,

- aktualność przekazywanych treści,

- wysoki poziom interakcyjności zajęć,

- wysoką motywację nauczycieli i uczniów,

- zapewnienie przygotowania merytorycznego, dydaktycznego i technicznego kadry prowadzącej zajęcia w formie zdalnej,

- kreowanie współodpowiedzialności za proces kształcenia u wszystkich uczestników KnO.

Największym wyzwaniem pozostaje badanie efektywności KnO i jego standaryzacja. Konieczne jest stworzenie spójnej metodologii, która pozwoliłaby na prowadzenie rozległych analiz determinantów składających się na szeroko pojętą efektywność kształcenia na odległość. Na dalszym etapie prac badawczych istotne wydaje się także stworzenie pewnych standardów w zakresie wspomnianej efektywności, które pozwoliłyby na ocenę kształcenia i wskazanie ewentualnych obszarów do poprawy. Celem powinna być także analiza trendu, która stworzyłaby możliwość porównywania osiąganych efektów w ramach $\mathrm{KnO}$ z perspektywy dłuższego czasu, co pozwoliłoby na bardziej świadome kształtowanie warunków niezbędnych dla podniesienia efektywności całego procesu. 


\section{BIBLIOGRAFIA}

Bednarek J., Lubina E., Ksztatcenie na odległość. Podstawy dydaktyki, Wydawnictwo Naukowe PWN, Warszawa 2008.

Burawoy M., The Extended Case Method. Four Countries, Four Decades, Four Great Transformations, and One Theoretical Tradition, Berkley, University of California Press, Los Angeles 2009.

Chomczyński P., Wybrane problemy etyczne w badaniach. Obserwacja uczestniczaca ukryta, Przegląd Socjologii Jakościowej, 2006, II, 1.

Chomczyński P., Raport z badań jakościowych i ilościowych pt. „Współpraca pracodawców ze szkołami zawodowymi - diagnoza sytuacji w województwie łódzkim" [w:] Czy patronat jest rozwiąaniem? Wspótpraca szkół zawodowych z pracodawcami w regionie tódzkim, red. P. Chomczyński, T. Kamiński, Wydawnictwo WSP w Łodzi, Łódź 2012.

Chomczyński P., Problemy nauczycieli zaangażowanych w kształcenie na odległość - wyniki terenowych badań jakościowych, E-mentor, 2015, 3(60).

Chomczyński P., Głowacka E., Mytkowski D., Naftyński M., Niedzielska E., Zieliński W., Diagnoza stanu ksztatcenia na odległość w Polsce i wybranych krajach Unii Europejskiej, Studio Linia, Warszawa 2013.

Dziewulak D., Kształcenie na odległość w wybranych państwach europejskich. Analizy, Biuro Analiz Sejmowych, 2012, 18(85), 24 października.

Eberle T., Maeder Ch., Organizational ethnography, [w:] Qualitative Research, 3rd Edition, Ed. D. Silverman, Sage, London 2011.

Frankfort-Nachmias Ch., Nachmias D., Metody badawcze w naukach społecznych, przekł. E. Hornowska, Wydawnictwo Zysk i S-ka, Poznań 2001.

Hammersley M., Atkinson P., Metody badań terenowych, przekł. S. Dymczyk, Wydawnictwo Zysk i S-ka, Poznań 2000.

Keashly L., Jagatic K., US perspectives on workplace bullying, [w:] Bullying and Emotional Abuse in the Workplace. International perspectives in research and practice, Eds S. Einarsen, H. Hoel, D. Zapf, C.L. Cooper, Taylor \& Francis, London-New York 2003.

Kirkpatrick D.L., Ocena efektywności szkoleń, Studio EMKA, Warszawa 2001.

Konecki K., Studia z metodologii badań jakościowych: teoria ugruntowana, Wydawnictwo Naukowe PWN, Warszawa 2000.

Kostera M., Antropologia organizacji: Metodologia badań terenowych, Wydawnictwo Naukowe PWN, Warszawa 2003.

Krueger N., The microfoundations of entrepreneurial learning and education. The handbook of university wide entrepreneurship, Edward Elgar Publishing, Cheltenham, UK 2009.

Löbler H., Learning entrepreneurship from a constructivist perspective, Technology Analysis \& Strategic Management, 2006, 18(1).

Patton M., Obserwacja - metoda badań terenowych, [w:] Ewaluacja w edukacji, red. L. Korporowicz, przekł. M. Kowalski, Oficyna Naukowa, Warszawa 1997.

Plewka Cz., Taraszkiewicz M., Uczymy się uczyć, „Pedagogium” Wydawnictwo OR TWP, Szczecin 2010.

Szczesna E., Dyskurs ksztatcenia digitalnego. Ontologia dyskursu ksztatcenia digitalnego i jego funkcje, Studia Edukacyjne, 2013, 26.

Szpilska M., Raport krajowy na temat stanu wizualizacji uczenia się w Polsce, Instytut Technologii Eksploatacji, Radom 2006. 